\title{
Kelola
}

\section{Implementasi Program Ujian Nasional Di SMA Negeri}

\author{
Chatarina Sitoresmi Triwiniastuti \\ Universitas Kristen Satya Wacana \\ chatarina.sitoresmi@gmail.com \\ Wahyu Sabatini \\ Universitas Kristen Satya Wacana \\ efendiviska@gmail.com
}

\begin{abstract}
This study aims to describe how communication, resources, bureaucratic structure and disposition in National Examination program implementation. The research approach is qualitative with triangulation analysis techniques and source triangulation. Data collection is done by interview, document study, and observation. Data analysis techniques include data reduction, data presentation, and conclusions. The subjects were principals, vice principals and proctors or technicians at SMA Negeri 1 Pabelan. The results showed that communication, resources, bureaucratic structure and disposition in SMA Negeri 1 Pabelan affected the UN program implementation. The conclusion: there is clear communication between the government and schools through workshops; availability of resources in the form of rules, human resources and adequate infrastructure; bureaucratic structure consists of committees compiled from the central and school levels and there are SOPs in the form of POS UN as guidelines for implementing the National Examination; implementer has the desire to implement policies with various attitudes in implementing the UN program.
\end{abstract}

Keywords: Implementation, National Examination, SMA Negeri 1 Pabelan

\section{Article Info}

Received date: 11 Desember 2018

Revised date: 25 Juni 2019

Accepted date: 25 Juni 2019

\section{PENDAHULUAN}

Pendidikan adalah upaya untuk meningkatkan taraf hidup manusia baik secara jasmani dan rohani. Hal tersebut sejalan dengan pandangan Ki Hajar Dewantara (Neolaka dan Neolaka; 2017: 11-12) bahwa pendidikan adalah daya upaya untuk memajukan budi pekerti, pikiran, serta jasmani anak, agar dapat memajukan kesempurnaan hidup yaitu hidup dan menghidupkan anak yang selaras dengan alam dan masyarakatnya. Sedangkan dalam Undang Undang No. 20/2003 (UU No. 20/2003) tentang Sistem Pendidikan Nasional, pendidikan adalah usaha sadar terencana untuk mewujudkan suasana belajar dan peroses pembelajaran agar peserta didik secara aktif mengembangkan potensi dirinya untuk memiliki kekuatan spiritual keagamaan, pengendalian diri, kepribadian, kecerdasan, akhlak mulia, serta keterampilan yang diperlukannya, masyarakat, bangsa, dan negara (Neolaka dan Neolaka; 2017:11-12).

Tujuan pendidikan nasional (UU No. 20/2003 Pasal 3) adalah mengembangkan kemampuan dan membentuk watak serta peradaban bangsa yang bermartabat dalam rangka mencerdaskan kehidupan bangsa, bertujuan untuk berkembangnya potensi 
peserta didik agar menjadi manusia yang beriman dan bertakwa kepada Tuhan Yang Maha Esa, berakhlak mulia, sehat, berilmu, cakap, kreatif, mandiri, dan menjadi warga negara yang demokratis serta bertanggung jawab. Melalui tujuan ini, pemerintah memberikan kebijakan pendidikan. Kebijakan yang tersebut terdiri atas program-program pendidikan yang harus dilaksanakan oleh setiap lembaga pendidikan. Program pendidikan oleh pemerintah untuk peningkatan mutu pendidikan di Indoensia.

Mutu menurut Crosby adalah sesuatu hal yang disyaratkan atau distandarkan (Conformance to requirement) untuk menjamin kualitas input, proses maupun outputnya (Sunaengsih; 2017: 22). Oleh karena itu, mutu pendidikan yang diselenggarakan sekolah dituntut untuk memiliki standar baku mutu pendidikan. Gambaran mutu pendidikan dapat dikenali melalui tanda-tanda operasional berupa (Ahman; 2007: 72):

1. Keluaran/kelulusan sekolah yang relevan dengan kebutuhan masyarakat

2. Nilai akhir sebagai salah satu alat ukur terhadap prestasi belajar siswa

3. Persentase lulusan yang dicapai semaksimal mungkin oleh sekolah

4. Penampilan kemampuan dalam semua komponen pendidikan.

Menurut Peraturan Pemerintah Nomor 19 Tahun 2005 tentang Standar Nasional Pendidikan, pelaksanaan pendidikan dikatakan bermutu apabila terselenggara sesuai dengan standar nasional pendidikan yang telah ditentukan. Dalam hal ini terdapat delapan standar pendidikan, yaitu: standar isi, standar proses, standar kompetensi lulusan, standar pendidik dan tenaga kependidikan, standar sarana dan prasarana, standar pengelolaan, standar pembiayaan, dan standar penilaian pendidikan. Kedelapan standar tersebut saling berkaitan untuk menunjang terselenggaranya proses pembelajaran yang bermutu (Muchtar:
2010: 69). Kedelapan standar tersebut perlu diperhatikan dalam proses pendidikan.

Pemerintah membuat program Ujian Nasional dan diimplementasikan sebagai alat untuk mengukur mutu pendidikan setiap lembaga sekolah. Ujian Nasional merupakan salah satu produk dari kebijakan evaluasi pendidikan di Indonesia (Umami; 2018: 83). Menurut Permendikbud No. 03 tahun 2013 Ujian Nasional adalah kegiatan pengukuran dan penilaian pencapaian kompetensi lulusan secara nasional pada mata pelajaran tertentu dalam kelompok mata pelajaran ilmu pengetahuan dan teknologi. Pemerintah membuat kebijakan bahwa Ujian Nasional yang pada prinsipnya merupakan evaluasi dari hasil proses belajar. Sedangkan menurut (Tilaar; 2006: 72), Ujian Nasional adalah upaya pemerintah untuk mengevaluasi tingkat pendidikan secara nasional dengan menetapkan standarisasi nasional pendidikan. Disimpulkan bahwa Ujian Nasional sebagai kebijakan pemerintah untuk evaluasi proses belajar dan pengetahuan mutu pendidikan.

Pada Ujian Nasional (Fahmi, 2011: 1) tujuan yang hendak dicapai bersifat ganda, tujuan pertama adalah untuk memantau mutu pendidikan, dan yang kedua untuk penentuan kelulusan peserta ujian. Soal ujian dimaksudkan untuk memantau mutu pendidikan dan untuk mengetahui kemampuan yang telah dimiliki dan yang belum dimiliki oleh siswa sesuai dengan standar kompetensi lulusan (SKL).

Dalam Peraturan Pemerintah Republik Indonesia No. 19 Tahun 2005 Tentang Standar Nasional Pendidikan Pasal 68 tertulis Hasil ujian nasional digunakan sebagai salah satu pertimbangan untuk: 1) Pemetaan mutu program dan/atau satuan pendidikan; 2) Dasar seleksi masuk jenjang pendidikan berikutnya; 3) Penentuan kelulusan peserta didik dari program dan/atau satuan pendidikan; 4) Pembinaan dan pemberian bantuan kepada 
satuan pendidikan dalam upayanya untuk meningkatkan mutu pendidikan.

Implementasi program melibatkan berbagai pihak sehingga memiliki mekanisme jejaring dan komponen multi sistem. Mulai dari perencanaan, pengadaan soal/logistik ujian penetapan nilai, distribusi soal sampai pada monitoring dan evaluasi (Hidayah; 2013: 37). Pelaksanaan atau implementasi kebijakan tidak lepas dari campur tangan pemerintah. Empat faktor yang menentukan keberhasilan atau kegagalan implementasi kebijakan menurut Edward III adalah (Tahir; 2015:62-63):

1. Komunikasi yaitu perintah untuk pengimplementasikan kebijakan harus disampaikan secara jelas, akurat, dan konsisten kepada orang-orang yang melaksanakan. Faktor komunikasi ini menunjukkan peranan sebagai acuan agar pelaksana kebijakan mengetahui persis apa yang akan mereka kerjakan. Ketidakjelasan akan mendorong terjadinya interpretasi yang salah (Winarno; 2008: 177). Dalam hal ini komunikasi oleh Pemerintah pusat terhadap pemerintah daerah dan satuan pendidikan.

2. Sumber daya (Resources) berperan dalam implementasi karena bagaimanapun jelas dan konsistennya ketentuan-ketentuan suatu kebijakan, jika para personil yang bertanggungjawab mengimplementasikan kebijakan kurang mempunyai sumbersumber untuk melakukan pekerjaan secara efektif, maka kebijakan tidak akan bisa efektif. Apabila aturan yang dibuat sudah jelas namun sumber daya tidak terpenuhi maka implementasi tidak efektif (Widodo; 2011: 98). Sumber daya misalnya berupa Undang-Undang, fasilitas, sumber daya manusia, kewenangan dalam implementasi program Ujian Nasional.

3. Sikap pelaksana (Dipotition): pelaku implementasi harus mempunyai keinginan untuk melaksanakan kebijakan tersebut. Sikap baik dan buruknya atau sikap mendukung atau menolak dari sisi pelaksana akan mempengaruhi proses pelaksanaan kebijakan. Disposisi pelaksana Ujian Nasional adalah kepala sekolah, guru, orang tua siswa, dan siswa. Menurut hasil penelitian Sailan (2016) diketahui bahwa siswa di SMK Komputer Mutiara Ilmu Makasar siap mental menghadapi UNBK.

4. Struktur organisasi termasuk tata aliran kerja birokrasi: terkadang birokrasi yang menjadi penghambat pengimplementasian kebijakan. Hal ini disebabkan tiap birokrasi memiliki prosedur-prosedur yang berbeda. Seperti birokrasi tingkat pemerintah pusat dan daerah pasti ada perbedaan. Terdapat dua karakteristik birokrasi (Winarno; 2008: 203) diantaranya adalah Standart Operating Prosedures (SOP) dan Fragmentasi. SOP adalah prosedur dasar kerja dan untuk menyamakan tidakan-tindakan pelaksana. Sedangkan fragmentasi adalah pembagian tugas dan tanggungjawab tiap birokrat/unit organisasi pelaksana.

Tahapan penyelenggaraan Ujian Nasional diaur oleh BNSP. Adapun tahapannya dapat dilihat pada gambar 1 .

\section{Tahapan Penyelenggaraan Ujian Nasional}

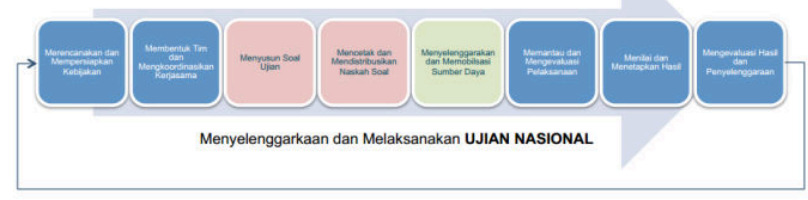

Gambar 1. Tahapan Penyelenggaraan Ujian Nasional. Sumber: BSNP 
Sesuai dengan ketentuan Peraturan Menteri Pendidikan dan Kebudayaan Nomor 3 Tahun 2017 tentang Penilaian Hasil Belajar oleh Pemerintah dan Penilaian Hasil Belajar oleh Satuan Pendidikan perlu menetapkan Prosedur Operasional Standar (POS) yang mengatur penyelenggaraan dan teknis pelaksanaan Ujian Nasional Tahun Pelajaran 2017/2018. Terdapat prosedur dalam tahapan pelaksanaan Ujian Nasional yang biasa dengan POS UN.

Terdapat beberapa penelitian relevan tentang Implementasi UN diantaranya dilakukan oleh Nur (2013) di Kota Palu menggunakan teori Merilee S. Grendle sebagai model penelitian. Model ini akan membawa peneliyi untuk memperoleh data tentang 1) Respeknya Anggota Masyarakat Pada Keputusan Pemerintah; 2)Adanya Kesadaran Untuk Menerima Kebijakan; 3) Adanya Kepentingan Publik; 4) Adanya sanksi Hukum; 5) Adanya Kepentingan Pribadi dan 6) Masalah Waktu. Hasil penelitian ini yaitu implementasi UN menunjukkan respon anggota masyarakat pada keputusan pemerintah menerima hasil ujian nasional, kesadaran untuk menerima kebijakan menunjukkan responden menerima baik pelaksanaan ujian nasional dan belum ada model lain untuk menggantikan, kepentingan publik telah terpenuhi semua, adanya kesadaran hukum untuk mengikuti semua aturan yang ada pada ujian nasional, ada minat pribadi pada realisasi ujian nasional, dan untuk waktu responden tidak memiliki masalah dengan pelaksanaan ujian nasional.

Asiah dan Rifieq (2011) meneliti implementasi ujian nasional di SMK. Hasil penelitian menunjukkkan bahwa perencanaan pelaksanaan ujian nasional sudah sesuai dengan prinsip-prinsip perumusan kebijakan meskipun masih terdapat kekurangan dan kelemahan yang harus diperbaiki, tahapan pengorganisasian sudah sejalan dengan prinsipprinsip perumusan kebijakan, tahapan pelaksanaan ujian nasional tingkat SMK tidak ada perubahan yang cukup berarti, dan tahap pengawasan dan evaluasi pada dasarnya sudah sesuai dengan prinsip-prinsip evaluasi meskipun untuk proses evaluasi kebijakan sebagai bagian untuk merencanakan kegiatan berikutnya tidak berjalan sebagaimana mestinya, oleh karena itu perlu ada upaya memperbaiki pelaksanaan ujian nasional dalam hal perencanaan kebijakan.

Alawiyah (2015) mengkaji perubahan kebijakan Ujian Nasional (UN) 2015, dimana pelaksanaan uji coba UN CBT berhasil dengan baik, tujuan UN tidak hanya mengukur hasil belajar siswa tetapi juga mengukur indeks integritas UN, dan hasilnya lebih dari 50\% sekolah yang melaksanakan UN memiliki IIUN yang sangat rendah.

Melalui paparan diatas akan dilakukan penelitian mengenai Implementasi Program Ujian Nasional di SMA Negeri 1 Pabelan Kabupaten Semarang. Penelitian ini penting dilakukan untuk mengetahui bagaimana komunikasi, sumber daya, disposisi dan birokrasi program Ujian Nasional.

\section{METODE PENELITIAN}

$\begin{array}{ccc}\text { Penelitian yang akan dilakukan } \\ \text { menggunakan } & \text { pendekatan } & \text { kualitatif. }\end{array}$ Pendekatan ini digunakan untuk memahami fenomena tentang apa yang dijalani oleh subjek penelitian secara holistik dan dengan cara deskripsi dalam bentuk kata-kata dan bahasa (Moleong; 2010: 6).

Penelitian ini dilakukan di SMA Negeri 1 Pabelan dengan alamat Desa Sumowo, Kec. Pabelan, Kab. Semarang, Prov. Jawa Tengah. Kode pos 50771. Subyek dalam penelitian ini adalah Kepala Sekolah SMA Negeri 1 Pabelan, Waka Kurikulum SMA Negeri 1 Pabelan, dan proctor Ujian Nasional tahun pelajaran 2017/2018 SMA Negeri 1 Pabelan. Peneliti memilih tiga informan sebagai sumber informasi karena dianggap memahami, mempunyai pengetahuan, dan terlibat langsung dalam implementasi Ujian Nasional. 
Model implementasi menggunakan Edward III dengan alasan bahwa sebuah kebijakan publik tanpa proses implementasi yang efektif, maka kebijakan tersebut tidak akan berjalan lancar. Sehingga model ini dianggap cocok dengan kondisi proses implementasi kebijakan ujian nasional berbasis komputer. Dimana di dalam model ini membahas empat indikator yaitu:

1. Proses komunikasi atau penyampaian informasi dari pemerintah pusat sampai ke pemerintah daerah dan satuan pendidikan untuk melaksanakan kebijakan UNBK. Proses komunikasi berhasil apabila ada kejelasan, keakuratan dan konsistensi dari pelaksana UNBK.

2. Sumber daya yang dimiliki harus bisa mendukung proses implementasi kebijakan agar dalam pelaksanaannya lebih efektif. Sumber daya tersebut berupa peraturan yang mengatur, fasilitas, sumber daya manusia, dan kewenangan dalam implementasi program Ujian Nasional tersebut.

3. Sikap dari pelaksana implementasi adalah kemauan, keinginan dan kecenderungan yang dimiliki untuk mendukung atau sebaliknya menolak kebijakan tersebut.

4. Struktur birokrasi yang ada bisa menghambat atau mendukung sebuah kebijakan. SOP dan fragmentasi harus jelas dan dapat dimengerti oleh pelaksana UNBK.

Teknik pengumpulan data terdiri dari teknik wawancara yaitu proses percakapan yang terdiri dari dua pihak, yaitu pihak peneliti "mengajukan pertanyaan dengan orang yang diwawancarai" (Bungin ;2011:155); teknik observasi (Nasution; 2012: 106) adalah cara untuk mendapatkan data dengan melakukan pengamatan keadaan yang wajar dan yang sebenarnya tanpa usaha yang disengaja untuk mempengaruhi, mengatur dan memanipulasikannya, dan teknik studi dokumen sebagai catatan tertulis yang berhubungan dengan suatu peristiwa masa lalu, baik yang di persiapkan maupun tidak dipersiapkan untuk suatu penelitian (Prastowo; 2010:191).

Teknik trianggulasi data yang digunakan yaitu teknik trianggulasi teknik dan trianggulasi sumber. Teknik validitas data yang digunakan dengan tiga aktivitas. Miles dan Hubermen (Sugiyono; 2013: 334-343), mengemukakan bahwa aktivitas dalam analisis data kualitatif dilakukan secara interaktif dan berlangsung secara terus menerus sampai tuntas, sehingga datanya jenuh. Ukuran kejenuhan data ditandai dengan tidak diperolehnya lagi data atau informasi baru. Aktivitas dalam analisis meliputi reduksi data, penyajian data serta penarikan kesimpulan dan verifikasi.

\section{HASIL PENELITIAN DAN PEMBAHASAN}

\section{Hasil Penelitian}

Program Ujian Nasional adalah program yang diselenggarakan pemerintah. Program ini ada sebagai kebijakan pendidikan untuk meningkatkan mutu pendidikan di Indonesia. Komunikasi Ujian Nasional melalui sosialisasi. Ujian Nasional disosialisasikan oleh pemerintah pusat kepada sekolah-sekolah melalui lokakarya tingkat provinsi maupun kabupaten/kota. Sosialisasi melalui lokakarya sangat jelas dalam memberikan penjelasan tentang Ujian Nasional. Pada tahun 2019 semua SMA/SMK wajib melaksanakan Ujian Nasional Berbasis Komputer (UNBK). UNBK menggunakan komputer sebagai media ujian, tidak lagi UNKP. UNBK didanai oleh pemerintah tetapi tidak dalam hal sarana dan prasarana. Sarana dan prasarana didanai oleh satuan pendidikan atau sekolah masing-masing. Peran Pemerintah yaitu dalam hal pembuatan kebijakan, pendanaan dan pendampingan pelaksanaan UNBK, sedangkan sekolah berkewajiban sebagai pelaksana kebijakan ujian nasional dan melaksanakan ujian nasional, membentuk tim atau kepanitiaan, 
memberikan jaminan lingkungan yang kondusif untuk pelaksanaan UNBK. Pemerintah dalam hal memberikan kebijakan pernah berubah yaitu untuk teknis pelaksanaan. Misalnya terjadinya perubahan jadwal pelaksanaan simulasi UNBK, aplikasi yang digunakan. Sehingga berdampak pada perlunya respon yang cepat tanggap dari penyelenggara tingkat satuan pendidikan terhadap perubahan yang terjadi.
Implementasi Program

UNBK melibatkan lingkungan internal dan eksternal sekolah. Lingkungan internal terdiri dari kepala sekolah, guru, tenaga kependidikan dan peserta didik, sedangkan lingkungan eksternal yaitu pemerintah pusat, pemda, kepolisian, komite sekolah, masyarakat, orang tua peserta didik dan PLN. Birokrasi pelaksanaan UNBK sebagai berikut:

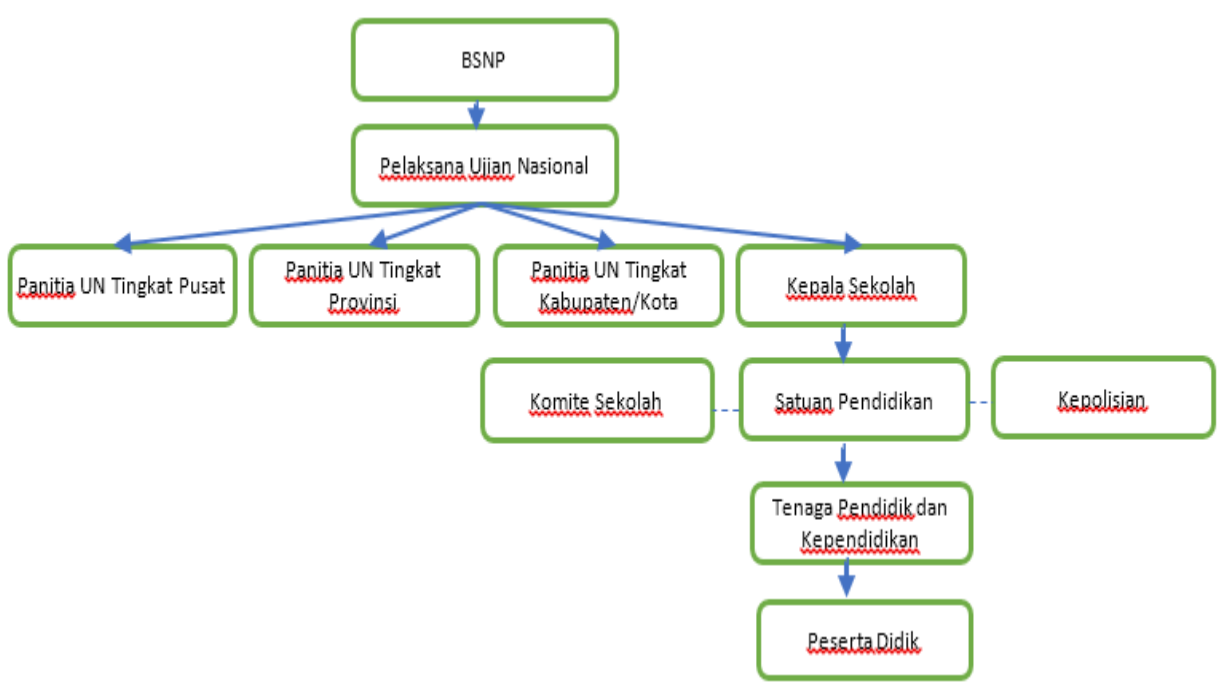

Gambar 1.2 Birokrasi pelasanaan UNBK

Koordinasi terjadi pada tingkat sekolah dan tingkat daerah. Tingkat sekolah dibawah koordiansi oleh kepala sekolah. Tingkat daerah dikoordinasi oleh kepala dinas pendidikan. Pelaksanaan UNBK pada tingkat satuan pendidikan menjadi tanggung jawab bersama antara Kepala Sekolah sebagai Penanggungjawab, Guru sebagai panitia dan proctor, tenaga kependidikan sebagai teknisi dan polisi sebagai keamanan.

Terdapat tata aturan UNBK yang terangkum dalam POS UNBK. Yang meliputi peserta UNBK, penyelenggaraan dan pelaksanaan UNBK, sarana dan prasaran yang dibutuhkan, bahan UNBK, aturan dan sanksi jika ada pelanggaran, penetapan proctor, teknisi dan pengawas ujian, serta kriteria pencapaian kelulusan. Proctor adalah tenaga ahli untuk mengendalikan server disekolah termasuk melayani peserta ujian dalam ketersediaan dan hambatan-hambatan dalam pelaksanaan ujian. Teknisi bertanggungjawab atas kesiapan server dari segi perangkat keras dan mananggani gangguan teknisi jaringan. Pengawas bertugas mengawasi jalannya ujian.

Terdapat kendala dalam pelaksanaan UNBK dalam hal teknis pada perangkat keras dan perangkat lunak. Walaupun terdapat kendala, proctor, teknisi, pengawas dan tim panitia bekerjasama dan saling mendukung satu sama lain.

Implementasi UNBK tidak lepas dari Sumber daya sebagai penunjang berjalannya program UNBK. Jumlah SDM yang diperlukan dalam pelaksanaan UNBK tergantung pada jumlah peserta UNBK. Terdapat dokumen tentang penetapan panitia UNBK, tupoksi proctor dan teknisi sera data peserta didik SMA Negeri1 Pablen yang mengikuti UNBK. Kriteria SDM pelaksannan UNBK seperti proctor dan teknisi yaitu harus memiliki pengetahuan tentang TIK, keterampilan 
pengelolaan LAN dan pernah mengikuti pelatihan di lokakarya sebagai proctor dan teknisi. Proctor dan teknisi diusulkan oleh sekolah dan diverivikasi oleh panitia UNBK tingkat provinsi. Pelaksanaan UNBK memerlukan fasilitas berupa perangkat server, client, jaringan lokal maupun internet, printer, scanner dan ruang ujian yang aman dan layak. SMA Negeri 1 Pabelan telah memiliki sarana dan prasarana yang cukup baik dalam pelaksanaan UNBK. Sarana dan prasarana lain seperti POS UN, jumlah dan spesifikasi komputer, listrik sudah terpenuhi. Informasi sebagai pedoman pelaksanaan terdapat pada POS UN dan mudah dipahami karena sebelumnya terdapat lokakarya yang diselenggarakan pemerintah. Adanya POS UN sangat membantu dalam pelaksanaan UN.

Program UNBK berkaitan dengan banyak pihak. Pihak-pihak tersebut menyikapi pelaksanaan UNBK dengan cara yang berbedabeda. Seperti, siswa mengganggap UNBK hanya sebagai kewajiban syarat kelulusan, ada yang menganggap bahwa hasil UNBK ini tidak berpengaruh pada kelulusan sehingga mereka tidak peduli dengan UNBK, tetapi ada beberapa peserta didik yang tetap menganggap bahwa UNBK ini penting dan harus mendapatkan nilai yang memuaskan meskipun tidak berpengaruh pada kelulusan. Sehingga mereka akan mengerjakan ujian dengan sungguh-sungguh. Sikap orang tua memberi dukungan yang baik memotivasi terhadap sekolah maupun siswa agar sukses UNBK, Sekolah mendukung program UNBK lewat segi pendanaan, dan guru mapel UNBK membantu siswa dalam mempersiapkan UNBK.

\section{Pembahasan}

Komunikasi. Ujian Nasional disosialisasikan oleh pemerintah pusat kepada sekolah-sekolah melalui lokakarya tingkat provinsi maupun kabupaten/kota. Sosialisasi melalui lokakarya sangat jelas dalam memberikan penjelasan tentang Ujian Nasional. Hal ini sejalan dengan hasil 60 penelitian bahwa sekolah melakukan perencanaan, pengorganisasian, pelaksanaan, pengawasan dan evaluasi tentang implementasi UN Asiah dan Rifieq (2011). Adanya lokakarya menandakan bahwa ada perencanaan untuk menyampaikan komunikasi kepada sekolah. Pada tahun 2019 semua SMA/SMK wajib melaksanakan Ujian Nasional Berbasis Komputer (UNBK). Hal ini sesuai dengan Teori Edward III tentang komunikasi harus disampaikan secara jelas, akurat, dan konsisten kepada orang-orang yang melaksanakan (Tahir; 2015: 62-63). Komunikasi dilakukan dengan cara sosialisasi melalui lokakarya, pernah mengalami perubahan dalam hal teknis namun dapat diatasi oleh sekolah. Walaupuan ada ketidak konsistenan oleh pemerintah, sekolah dapat mengatasi hal tersebut. Hal ini menandakan bahwa komunikasi oleh pemerintah dirasakan jelas oleh sekolah sehingga interpretasi satu dengan yang lain sama. Sejalan dengan Winarno bahwa ketidakjelasan akan mendorong terjadinya interpretasi yang salah (Winarno; 2008: 177 ).

Sumber daya. Widodo dalam bukunya menjelaskan apabila aturan yang dibuat sudah jelas namun sumber daya tidak terpenuhi maka implementasi tidak efektif (Widodo; 2011: 98). Pada hasil temuan lapangan jumlah SDM yang diperlukan dalam pelaksanaan UNBK tergantung pada jumlah peserta UNBK. SDM yang diperlukan pelaksanaan UNBK adalah proctor, teknisi dan pengawas ujian. Selain itu sudah tersedia POS UN sebagai pedoman dan aturan pelaksanaan UNBK, fasilitas seperti ruangan, jumlah dan spesifikasi komputer, listrik, jaringan internet, server memenuhi kebutuhan UNBK. Dapat disimpulkan bahwa sumber daya untuk implementasi UNBK telah terpenuhi. Sumber daya sangat diperlukan dalam implementasi UNBK. Sumber daya yang ada disekolah baik aturan, SDM maupun sarana dan prasarana telah terpenuhi dan menjadikan UNBK efektif. 
Disposisi/Sikap Pelaksana. Siswa melaksanakan program UNBK hanya sebagai syarat kelulusan dan melakukan dengan serius dengan motivasi mendapatkan nilai yang baik. Menurut hasil penelitian oleh Sailan (2016) diketahui bahwa siswa di SMK Komputer Mutiara Ilmu Makasar siap mental menghadapi UNBK. Peneliti memandang bahwa siswa yang melakukan UNBK dengan serius dapat dikatakan bahwa siswa tersebut siap secara mental. Orang tua siswa mendukung dan memotivasi siswa dan sekolah supaya sukses dalam pelaksana UNBK sehingga sesuai dengan hasil penelitian terdahulu yang mengatakan bahwa masyarakat menerima kebijakan tentang Ujian nasional Nur (2013) . Guru mata pelajaran membantu siswa mempersiapkan UNBK melalui pemadatan. Sekolah menyiapkan dana untuk pelaksanaan UNBK. Seperti yang dipaparkan oleh teori disposisi oleh Tahir yang mengatakan bahwa pelaku implementasi harus mempunyai keinginan untuk melaksanakan kebijakan tersebut (Tahir; 2015:62-63). Keinginan sekolah dalam melaksanakan UNBK terlihat dari adanya kepanitian UNBK bahkan guru juga melaksanakan les tambahan mata pelajaran UNBK bagi siswa disekolah. Sikap baik dan buruknya atau sikap mendukung atau menolak dari sisi pelaksana akan mempengaruhi proses pelaksanaan kebijakan. Peneliti menyimpulkan bahwa siswa, orang tua, guru dan pihak sekolah mendukung program UNBK. Namun, terdapat sikap siswa yang buruk dalam melaksanakannya. Sikap baik terdapat pada guru, sekolah dan orang tua.

Birokrasi. Terdapat dua karakteristik birokrasi (Winarno; 2008: 203) yaitu Standar Operating Prosedures (SOP) dan Fragmentasi. SOP adalah prosedur dasar kerja untuk menyamakan tidakan-tindakan pelaksana. Sedangkan fragmentasi adalah kondisi perpecahan antar para pihak dalam birokrasi pelaksana program karena pembagian tugas dan tanggungjawab dalam unit organisasi pelaksana. Temuan di lapangan menunjukkan bahwa terdapat informasi sebagai pedoman pelaksanaan UN dalam bentuk POS UN. Hal ini sesuai dengan ketetapan Peraturan Menteri Pendidikan dan Kebudayaan Nomor 3 Tahun 2017 tentang Penilaian Hasil Belajar oleh Pemerintah dan Penilaian Hasil Belajar oleh Satuan Pendidikan yang menyatakan perlunya ditetapkan Prosedur Operasional Standar (POS) yang mengatur penyelenggaraan dan teknis pelaksanaan Ujian Nasional Tahun Pelajaran 2017/2018. Selain POS UN, terdapat tata aturan UNBK yang terangkum dalam SOP UNBK. SOP mengatur mengenai peserta UNBK, penyelenggaraan dan pelaksanaan UNBK, bahan UNBK. SOP dan POS UN ini memenuhi akan kriteria birokrasi yaitu adanya SOP.

Tentang fragmentasi birokrasi dalam implementasi UN dapat dikatakan bahwa walaupun terdapat rentang biirokrasi pelaksana mulai dari BSNP sebagai penyelenggara program Ujian Nasional yang dibawahnya terdapat pelaksana UN yang terdiri dari panitia UN tingkat pusat, tingkat provinsi, tingkat kabupaten/kota, kepala sekolah, satuan pendidikan yang sejajar dengan komite sekolah dan kepolisian, tenaga pendidik dan kependidikan serta siswa. Pada tingkat sekolah, kepala sekolah sebagai Penanggungjawab, Guru sebagai panitia dan proctor, tenaga kependidikan sebagai teknisi, PLN untuk askses listrik dan polisi sebagai keamanan, namun tidak terdapat fragmentasi di antara para pelaksanan UN tersebut. Padahal penyelenggaraan UN ini tidak hanya melibatkan SDM pada bidang pendidikan tetapi melibatkan polisi untuk kemananan dan PLN untuk mengendalikan listrik. Ketiadaan fragmentasi ini antara lain disebabkan karena adanya pembagian tugas yang jelas di antara berbagai unit birokrasi dan masing-masing melakukan tugasnya serta melakukan koordinasi dengan baik. 


\section{SIMPULAN DAN SARAN}

\section{Simpulan}

Implementasi program Ujian Nasional di SMA Negeri 1 Pabelan dapat dilaksanakan dengan baik. Bentuk komunikasi oleh pemerintah pusat dilakukan dengan sosialisasi melalui lokakarya yang dilaksanakan pada tingakat kabupaten/kota. Ketidakonsistenan pemerintah pernah terjadi dalam hal teknis pelaksanaan UNBK. Namun, dapat datasi oleh sekolah. Hal ini menandakan bahwa komunikasi yang dilakukan pemerintah terhadap sekolah ada kejelasan.

Sumber daya dalam implementasi program Ujian Nasional di SMA Negeri 1 Pabelan telah terpenuhi baik secara SDM, sarana dan prasarana sehingga implementasi dapat menajdi efektif. Sumber daya yang ada meliputi SDM seperti pengawas ujian, proctor dan teknisi sebagai pelaksana UNBK. Sumber daya lainnya adalah sarana dan prasarana, meliputi: fasilitas seperti ruangan, jumlah dan spesifikasi komputer, listrik, jaringan internet, server memenuhi kebutuhan UNBK. Aturan sebagai bentuk sumber daya yaitu POS UN sebagai pedoman dan aturan pelaksanaan UNBK.

Sikap pelaksana dalam melaksanakan program Ujian Nasional termasuk positif karena para pelaksanan mempunyai keinginan untuk melaksanakan kebijakan UNBK sebaik mungkin. Peneliti menyimpulkan bahwa siswa, orang tua siswa, guru dan pihak sekolah memiliki sikap positif dan mendukung program UNBK, walaupun terdapat sikap beberapa siswa yang buruk dalam pelaksanakan UNBK.

Dari sisi birokrasi sudah tersedia SOP bagi UNBK berupa Prosedur Operasional Standar (POS) yang mengatur penyelenggara an dan teknis pelaksanaan Ujian Nasional. Pada sisi lain terjadi fragmentasi antar panitia UNBK tingkat pusat dan tingkat sekolah serta pihak keamanan yang tentunya melibatkan pihak dinas pendidikan, satuan pendidikan, polisi dan PLN karena para pihak justru saling bekerjasama sesuai dengan tugas masingmasing.

\section{Saran}

Berdasarkan hasil penelitian di atas peneliti memberikan beberapa aran agar penyelenggaraan program UNBK di SMA Negeri 1 Pabelan dapat menjadi lebih baik di masa yang akan datang. Sekolah hendaknya terus proaktif dalam menerima komunikasi dari pemerintah sehingga apabila terjadi ketidakjelasan maupun ketidakkonsistenan dapat ditangani dengan baik. Sumber daya baik secara aturan, SDM dan sarana prasarana terus diperbarui seiring dengan kebutuhan program UNBK supaya tidak terjadi kegagalan dalam pelaksanaan program UNBK. Para pihak yang terlibat dalam pelaksanaan program UN perlu diberi motivasi dan cara pandang yang baik agar memiliki keinginan untuk menyukseskan program UNBK. SOP sebagai pendoman pelaksanaan UNBK perlu diperhatikan lebih baik lagi.

\section{DAFTAR PUSTAKA}

Ahman. Kartadinanta, Karman. (2007). Ilmu dan Aplikasi Pendidikan. Bandung: Grasindo.

Anonim. (2007). Undang-undang Republik Indonesia Nomor 20 Tahun 2003 tentang Sistem Pendidikan Nasional \& Undang-undang Republik Indonesia Nomor 14 Tahun 2005 Tentang Guru dan Dosen. Jakarta: Visimedia.

Asiah, Siti dan Rifieq, Ainur. (2011). Analisis Kebijakan Ujian Nasional Tingkat Sekolah Menengah Kejuruan (SMK), Edukasi, Vol. 3 (1) Maret hal: 75 - 92

Alawiyah, Faridah (2015), Perubahan Kebijakan Ujian Nasional (Studi Pelaksanaan Ujian Nasional 2015), Aspirasi Vol. 6 (2), Desember 2015 hal: 189-202. 
Bungin, Burhan. (2011). Metode Penelitian Kualitatif. Jakarta: PT Raja Grafindo Persada.

Fahmi, Amiq. (2011). Seminar Nasional Teknologi Informasi \& Komunikasi Terapan 2011 (Semantik 2011): Desain Model Sistem Ujian Online

Sailan, Manan. (2016). Persepsi Siswa Tentang Pelaksanaan Ujian Nasional Berbasis Kompuer Di SMK Komputer Mutiara Ilmu Makasar. Jurnal Pemikiran Penelitian Hukum Dan PPKn Vol. 3 No. 2 Juni

Hidayah, Nurul. (2013). Ujian Nasional dalam Perspektif Kebijakan Publik. Jurnal Pencerahan Volume 7 ()1, Maret, hal: 37

Moleong, Lexy J. (2010). Metodologi Penelitian Kualitatif. Bandung: PT Remaja Rosda Karya.

Muhctar, Hartati. (2010). Penerapan Penilaian Autentik dalam Upaya Peningkatan Mutu Pendidikan. Jurnal Pendidikan Penabur No.14/Tahun ke-9/Juni, hal: 69.

Nasution. (2012). Metode Research: Penelitian Ilmiah. Jakarta: PT Bumi Aksara.

Neolaka, Amos. Grace Amialia A. Neolaka. (2017). Landasan Pendidikan Dasar Pengenalan Diri Sendiri Menuju Perubahan Hidup. Depok: Kencana,

Prastowo, Andi. (2010). Menguasai Teknikteknik Data Penelitian Kualitatif. Yogyakarta : IKAPI.
Sugiyono. (2013). Metode Penelitian Kombinasi (Mixed Method). Bandung: Alfabeta,.

Sunaengsih, Cucu. (2017). Pengelolaan Pendidikan. Sumedang: UPI Sumedang Press, 2017

Tahir, A. (2015). Kebijakan Publik dan Transparansi Penyelenggaraan Pemerintahan Daerah. Jakarta: Penerbit PT Pustaka Indonesia Press

Tilaar. H.A.R. (2006). Standarisasi Pendidikan Nasional: Suatu Tinjauaan Kritis. Jakarta. Rineka Cipta.

Umami, Dody Rijal. \& Eni Roesminingsih. (2014). Pengaruh Kompetensi Pedagogik Dan Motivasi Kerja Guru Terhadap Prestasi Belajar Siswa Dalam Ujian Nasional (UN) di SMA Negeri Se Kota Mojokerto; Jurnal Inspirasi Manajemen Pendidikan Vol 3 (3) Januari, hal: 83.

Widodo, J. (2011). Analisis Kebijakan Publik. Malang: Bayumedia.

Winarno, Budi. (2008). Kebijakan Publik (Teori, Proses dan Studi Kasus). Yogyakarta: CAPS.

Nur, Muhammad. (2013). Implementasi Kebijakan Pelaksanaan dan Analisis Hasil Ujian Nasional Di Kota Palu Provinsi Sulawesi Tengah, e-Jurnal Katalogis, Volume I (2), Februari hal: 153-161 